\title{
THE CHALLENGE OF BIBLICAL THEOLOGY
}

\section{Charles H.H. Scobie}

The term 'Biblical Theology' is still widely used today. There are encyclopedias of Biblical Theology, journals devoted to Biblical Theology, and people occupy chairs of Biblical Theology. In recent years there has been renewed discussion of the possibility of producing a Biblical Theology, a development which has given rise to hope in some, but suspicion in others. ${ }^{1}$ Examination of the various uses of the term, however, quickly reveals widespread disagreement regarding its meaning. 'Biblical theology', as J.L. McKenzie has said, 'is the only discipline or sub-discipline in the field of theology that lacks generally accepted principles, methods and structure. There is not even a generally accepted definition of its purpose and scope'.2 Indeed, on some definitions it is likely that there are many scholars who would hold that Biblical Theology either does not or should not exist at all.

\section{The Problem of Definition}

If real progress is to be made in the study of Biblical Theology the question of definition is clearly crucial. By far the commonest procedure is to refer back to the origins of the actual phrase 'Biblical Theology' (theologia biblica, biblische Theologie) and in particular to link the definition of Biblical Theology with the famous inaugural address of J.P. Gabler at the University of Altdorf in 1787, entitled 'An Oration on the Proper Distinction Between Biblical and Dogmatic Theology and the Specific Objectives of Each'. ${ }^{3}$ The general assumption

\footnotetext{
${ }^{1}$ See P. Höffken, 'Anmerkungen zum Thema Biblische Theologie', in M. Oeming and A. Graupner, Altes Testament und christliche Verkündigung (Stuttgart, W. Kohlhammer, 1987) 13.

2J.L. McKenzie, A Theology of the Old Testament (Garden City, Doubleday, 1974) 15.

3'Oratio de iusto discrimine theologiae biblicae et dogmaticae regundisque recte utriusque finibus', in T.A. Gabler and J.G. Gabler, (edd.) Kleinere theologische Schriften, II (Ulm, Verlag der Stettinischen Buchhandlung, 1831) 179-98. An English translation is available in J. Sandys-Wunsch and L. Eldredge, J.P.
} 
is that Gabler advocated the strict separation of Biblical Theology and Dogmatics. Biblical Theology is thus defined as a purely historical and descriptive discipline standing apart from the Christian tradition.

This approach will be examined and some indication given of the problems which it entails. An alternative approach to definition will then be offered, one which seeks to define Biblical Theology in relation to the Christian tradition rather than over against it. The merits of these two approaches will be assessed in the light of the history of Biblical Theology over the past 200 years, and in the light of the impasse in which the discipline finds itself today. Finally, after briefly reviewing some recent developments which give promise of opening up new horizons, an attempt will be made to define and describe a viable approach to Biblical Theology today.

\section{i. Biblical Theology apart from the Christian tradition}

Virtually every discussion of Biblical Theology today begins with at least a brief reference to the alleged origins of the discipline in the late 18th century. The past twenty years have seen the publication of a series of valuable studies of the history of Biblical Theology ${ }^{4}$ and these have made an important contribution to the understanding of the history of biblical studies.

As far as is known the earliest use of the term 'Biblical Theology' is in the title of a book Teutsche biblische Theologie

Gabler and the Distinction Between Biblical and Dogmatic Theology: Translation, Commentary and Discussion of His Originality', SJT 33 (1980) 13358. The 200th anniversary of the address prompted scholarly re-evaluation: see M. Saebo, 'Johann Philip Gablers Bedeutung für die Biblische Theologie: zum 200-jaehrigen Jubileum seiner Antrittsrede vom Maerz 1787', ZAW 99 (1987) 1-16; R. Morgan, 'Gabler's Bicentenary', ET 98 (1987) 1648.

${ }^{4}$ H.J. Kraus, Die Biblische Theologie: Ihre Geschichte und Problematik (Neukirchen-Vluyn, Neukirchener Verlag 1970); W. Harrington, The Path of Biblical Theology (Dublin, Gill and Macmillan 1973); G.F. Hasel, Old Testament Theology: Basic Issues in the Current Debate (Grand Rapids, Eerdmans 1975 rev.ed.); G.F. Hasel, New Testament Theology: Basic Issues in the Current Debate (Grand Rapids, Eerdmans 1978); H.G. Reventlow, Problems of Biblical Theology in the Twentieth Century (Philadelphia, Fortress 1977); J. Smart, The Past, Present and Future of Biblical Theology (Philadelphia, Westminster 1979); M. Oeming, Gesamtbiblische Theologien der Gegenwart (Stuttgart, Kohlhammer 1987 2nd.ed.) 
by W.J. Christmann, published in 1629 (no copies of the book itself are known to have survived). Fifteen years later H.A. Diest published a volume entitled Theologia Biblica. ${ }^{5}$ These were early examples of a series of works produced within the Protestant Orthodoxy of the 17th and 18th centuries consisting of collections of proof texts (dicta probantia) compiled (along with exegetical comments) in order to demonstrate the biblical basis of Protestant doctrine. Clearly this approach instead of permitting the Scripture to speak for itself ... sought, actually, to compress the Bible within the narrow confines of a dogmatic system ${ }^{\prime}{ }^{6}$

More influential was the use of the term in both Pietism and Rationalism, which represented different reactions against Protestant Orthodoxy and both of which were influenced by the emerging 'historical-critical' (or 'grammatico-historical') approach to the study of the Bible. Pietism turned to the Bible not as a quarry of proof-texts but primarily for spiritual and theological nourishment. P.J. Spener (1635-1705) contrasted 'biblical theology' (theologia biblica) with the prevailing Protestant 'scholastic theology' (theologia scholastica), ${ }^{7}$ and in the 18th century several Pietists published works with the term 'Biblical Theology' in the title.

The other assault upon Orthodoxy came from the Rationalism of the late 18th century, which developed from English Deism and the German Enlightenment, and which sought to extract from the Bible universal and timeless truths, in accordance with reason, distinguishing them from what is merely historically conditioned and timebound. This approach is seen in the work of K.F. Bahrdt ${ }^{8}$ and especially in G.T. Zachariä's five volume Biblische Theologie published between 1771 and 1786. ${ }^{9}$ W.F. Hufnagel in his Handbuch der biblischen

\footnotetext{
${ }^{5}$ H.A. Diest, Theologia Biblica (Daventriae, Ioannem Janssonium 1643).

6J.H. Hayes and F. Prussner, Old Testament Theology: Its History and Development (Atlanta, John Knox 1984) 19.

7See G. Ebeling, "The Meaning of "Biblical Theology"', in Word and Faith (Philadelphia, Fortress 1963) 84.

${ }^{8}$ Versuch eines biblischen Systems der Dogmatik, 2 vols. (Gotha/Leipzig, Heinsius 1769-70).

${ }^{9}$ Biblische Theologie, oder Untersuchung des biblischen Grundes der vornehmsten theologischen Lehren (Tübingen, Frank und Schramm 1771-86). See J. Sandys-Wunsch, 'G.T. Zechariä's Contribution to Biblical Theology',
} 
Theologie (1785-9) enunciated the dictum that 'the proof-texts must be used to correct the theological system, not the system the proof-texts' ${ }^{10}$

This is the point at which Gabler's much alluded to address enters the picture. Recent studies have shown Gabler's debt to his predecessors and also questioned the extent of his immediate influence. ${ }^{11}$ Be that as it may, the title of Gabler's address does bring to a focus a highly significant trend which was already under way in 1787 and which became increasingly influential, indeed remaining so down to the present day. This is the idea of making a clear distinction between Biblical Theology which is a purely historical and descriptive science, and Dogmatic Theology which is the ever-new task of relating biblical truths to contemporary life and thought. In fact this remains the basis for most modern definitions of Biblical Theology. In G. Ebeling's words, Biblical Theology is to be understood as 'the theology contained in the Bible, the theology of the Bible itself', which is a 'historical concept', not 'the theology that accords with the Bible, scriptural theology', which is a 'normative concept'.12 In a much-quoted article in the Interpreter's Dictionary of the Bible Kristar Stendahl expressed the distinction by saying that Biblical Theology deals with what the biblical text 'meant' whereas Dogmatic Theology deals with what it 'means' ${ }^{13}$

This approach to the definition of Biblical Theology involves a number of serious problems.

(a) First of all, it will be observed that the standard definition is not in fact in accordance with the earliest use of the term 'Biblical Theology'. This relates to the dicta probantia (prooftext) approach which virtually no one would support today.

Nor as it happens (and as will be discussed more fully below) is the standard definition entirely in accordance with the views of Gabler himself, contrary to the impression given

ZAW 92 (1980) 1-23.

${ }^{10}$ Quoted in R.C. Dentan, Preface to Old Testament Theology (New York, Seabury 1963) 20.

11 See especially J. Sandys-Wunsch and L. Eldredge, op. cit.

${ }^{12} \mathrm{G}$. Ebeling, op. cit., 79.

${ }^{13} \mathrm{~K}$. Stendahl, 'Biblical Theology, Contemporary', The Interpreter's Dictionary of the Bible (New York, Abingdon 1962), Vol. 1, 418-32. 
by the title of his address. (It appears that many scholars have read only the title of the address, not the address itself). In other words, from the outset the term 'Biblical Theology' was ambiguous. Hence a simple appeal to the origins of the term is not particularly helpful. Definition must be based on a more secure foundation than this.

(b) Secondly, it must surely be the case that Biblical Theology as a field of study is not necessarily to be limited by the use of the (relatively modern) label 'Biblical Theology'; conversely, not everything which has been labelled 'Biblical Theology' in the past two or three hundred years necessarily merits being thus designated.

(c) In the third place, as we shall see more fully below, the programme for an independent, purely historical and descriptive discipline which did flourish from the late 18th century onwards, led not to the development of Biblical Theology but first to its division, then to its decline and virtual demise. Under the influence of the rapidly evolving historical-critical methodology 'Biblical Theology' (socalled) increasingly drove a wedge between academic biblical studies and the use of the Bible by the Church in dogmatics and related fields. Biblical Theology was (and still is by many) defined over against the on-going Christian tradition.

\section{ii. Biblical Theology in relation to the Christian tradition}

A more satisfactory procedure, it is suggested here, is to begin with an understanding of the Bible as the canonical Scriptures of the Christian Church, and with an examination of the component terms of the phrase 'Biblical Theology'.

The adjective 'biblical' comes from the noun 'Bible' which in turn derives ultimately from the Greek ta biblia meaning 'the books'. While the term can be used loosely (e.g. 'The Koran is the Bible of Islam'), for our purposes it is here defined as the 'books' or 'scriptures' accepted as canonical by the Christian Church, i.e the books of 'the Old Testament' and 'the New Testament' together.

'Theology' identifies the concern of the discipline as theos, 'God'. A Biblical Theology will deal with God as he has revealed himself in the biblical tradition, and by common 
consent this includes God's relation to the world and to humankind. There is certainly room for difference of opinion regarding the boundaries of such a theology. For example, should it include at least the theological basis of ethics, or is Biblical Ethics a completely different subject from Biblical Theology?

'Theology' means the logos of theos, and this raises perhaps the most contentious aspect of any definition of Biblical Theology. 'Logos ('word', 'language', 'reason') in compounds of this type generally denotes the written, rational, systematic, scientific study of a given subject area. There are those who would contend that since the biblical material is so diverse, and with its varied literary forms (history, poetry, drama, epistles, and so on) actually contains very little 'theology', therefore a Biblical Theology is virtually impossible. Such a view, it may be argued, presupposes a very narrow conception of theology as rigid, systematized, doctrinal and propositional in form. Through its diverse literary forms the Bible does give expression to an understanding (or understandings) of God in his relation to the world and to humankind. It is the testimony of the community which accepts the Bible as canonical scripture that this understanding, though diverse and culturally conditioned, nevertheless is based on the revelation of God; in and through the human words can be discerned the Word of God. This understanding of God's revelation can be the subject of scholarly study. Such study, as in any discipline, must be ordered in some way; what is important is that the 'order' is one that arises from and is appropriate to the subject matter itself. ${ }^{14}$

Broadly then, Biblical Theology may be defined as the ordered study of the understanding of the revelation of God contained in the canonical scriptures of the Old and New Testaments. Implicit in this definition are two major challenges which the Church has had to face from its earliest days. One is the problem of identifying the unity within the

${ }^{14}$ Cf. G.F. Hasel, 'The Relationship Between Biblical Theology and Systematic Theology', Trinity Journal 5 (1984) 126: 'A degree of systematizing the material content of the biblical books and groups of writing is inevitable, but the principles for systematizing must derive inductively from Scripture itself'. 
diversity of scripture. When the term biblia passed from Greek to Latin it also passed from the neuter plural ('the books') to feminine singular ('the book'). Thus the very term 'Bible' is a vivid reminder of the tension between diversity and unity, a tension which arises in its most acute form through the juxtaposition of 'Old Testament' and New Testament' within the one Bible. The other challenge is to discern how the Word of God, so closely tied to past history, speaks anew to the community of faith in each succeeding age. Modern historical studies have widened the gap between the cultural milieu in which the biblical books were written and that in which the modern interpreter stands, thus exacerbating the problem. In brief these constitute the challenge of biblical interpretation or hermeneutics with which the Church must constantly wrestle, and to which it has offered a variety of responses over the centuries.

\section{The History of Biblical Theology}

\section{i. An integrated Biblical Theology}

On this definition it is clear that some form of Biblical Theology was practised in the early Church and in the patristic and medieval periods. ${ }^{15}$ As early as the time of Irenaeus, i.e. well before the finalization of the New Testament canon, we nevertheless have a Christian writer who in defending the Christian faith in face of the Gnostic threat turns to the Church's Scriptures and seeks to understand them in an ordered way, dealing with the relation of the Old Testament to the new Christian Scriptures, and dealing also with the problem of diversity as seen, for example in the plurality of the Gospels. ${ }^{16}$

It is true that no distinction was made between the study of the understanding of God and his purpose in the Scriptures and what we would call dogmatic theology; the one form of activity simply merged into or was integrated with the

${ }^{15} \mathrm{Cf}$. H. Clavier, 'Les Données Bibliques et leur Interprétation: Principes de Théologie Biblique', in E.A. Livingstone, ed., Studia Biblica 1978. I. Papers on Old Testament and Related Themes (Sheffield, JSOT Supp.11, 1979) 65; P. Robertson, 'The Outlook for Biblical Theology', in D.F. Wells, C.H. Pinnock, edd., Toward a Theology for the Future (Carol Stream, Creation House 1971) 65. ${ }^{16}$ See J. Lawson, The Biblical Theology of St. Irenaeus (London, Epwort, 1948). 
other. The type of Biblical Theology practised by many of the Church Fathers and indeed on into medieval times could therefore be termed 'integrated Biblical Theology'. In this period allegorical interpretation was the dominant method employed in coping with the diversity of scripture.

When we come to the Reformers it is even more difficult to deny that Luther and Calvin, with their appeal over the head of centuries of Church tradition to the teaching of Scripture (sola scriptura) practised a form of Biblical Theology. They did seek to grasp the overall structure of the biblical understanding of God and his relations with mankind, and in so doing confronted some of the most basic challenges of Biblical Theology. Luther's dialectic of Law and Gospel and his use of 'Justification by Faith' as a hermeneutical key are important and original contributions to the solution of the problem of unity and diversity in Scripture. Yet even here, in a way which from our perspective we find difficult to understand, there was no explicit differentiation between biblical and dogmatic theology. In their case also Biblical Theology was integrated with Dogmatic Theology.

\section{ii. An independent Biblical Theology}

As we have already noted the idea of an independent Biblical Theology arose in the late 18th century in the context of reactions by both Pietism and Rationalism to Protestant Orthodoxy, and especially under the impetus of the newly emerging historical critical methodology. Rationalists saw in this new approach an objective method by which to throw off the shackles of centuries of Church dogma and penetrate back to the true teaching of the Christian faith. 19th century liberals used historical criticism in 'the quest of the historical Jesus', seeking norms for Christian living in the teaching of 'the real Jesus' thereby revealed.

The historical approach created new problems and challenges for Biblical Theology as it began to reveal more and more of the diversity and the development within the biblical record, and above all the gap which separates the Old Testament from the New. It is true that a number of 'Biblical Theologies' continued to be produced in the first half of the 19 th century, but as early as 1796 G.L. Bauer led the way by 
producing a Biblische Theologie des Alten Testaments which was followed a few years later by a quite separate Biblische Theologie des Neuen Testaments. ${ }^{17}$ By mid-century the writing of 'Biblical Theology' had virtually ceased and the production of separate Old Testament Theologies and New Testament Theologies had become the standard practice even among relatively conservative scholars.

By the end of the 19th century so-called theologies of the Old and New Testaments tended to become increasingly histories of the religion of Israel and of early Christianity. The mass of material on the Ancient Near East and the GraecoRoman world becoming available encouraged the History of Religions (Religionsgeschichte) approach which for many appeared to call in question the uniqueness of biblical faith. The true subject matter of the Bible was seen not as 'theology' but as 'religion', and since the historian must consider all the available evidence the idea of the canon was rejected as irrelevant. According to $\mathrm{W}$. Wrede, New Testament Theology is purely historical and descriptive and is 'totally indifferent to all dogma and systematic theology ${ }^{\prime 18}$

With Wrede we have arrived at a completely independent Biblical Theology. This approach has continued to develop and to flourish in academic circles. It is associated with the movement in the European setting of a considerable portion of biblical studies from the theological seminary to the university, and also, especially in North America in the second half of the 20th century, with the blossoming of university 'departments of religious studies'. While it is dangerous to generalize it often seems to be an underlying assumption that such an approach, unfettered by any Christian dogmatic presuppositions, is somehow objective and neutral and thus the only one which is possible in scholarly and academic circles.

The question may be raised, however, whether such an approach is either 'biblical' or 'theology'. When the limits of the canon are totally ignored, when the Book of Enoch is just as

${ }^{17}$ G.L. Bauer, Theologie des Alten Testaments (Leipzig, Weygand 1796); Biblische Theologie des Neuen Testaments (Leipzig, Weygand, 1800-2 ).

${ }_{18} \mathrm{~W}$. Wrede, Über Aufgabe und Methode der sogennanten neutestamentliche Theologie (Göttingen, Vandenhoeck \& Ruprecht, 1897); English translation in R. Morgan, The Nature of New Testament Theology (London, SCM 1973) 69. 
much source material as the Book of Isaiah, or I Clement as much as I Corinthians, it hardly makes sense to say that the discipline is concerned with the 'Bible', the canonical scriptures of the Christian Church. Similarly, when the sole concern is to describe the religion of these communities and no recognition is given to the documents as being in any way theologically normative it is hard to see how 'theology' is an appropriate designation. There is no intention here of denying the legitimacy of a History of Religions approach (though whether this can ever be neutral or presuppositionless is another matter); what is being questioned is the appropriateness of retaining the terms 'Biblical Theology', 'Old Testament Theology' and New Testament Theology' for such an approach.

Wrede in fact, in the title of his methodological essay, referred to 'so-called (sogennante) New Testament Theology'. R. Smend's Lehrbuch der alttestamentlichen Religionsgeschichte (1893) inaugurated a series of works generally designated as 'histories of religion'. Usage has not been consistent, however, and the term 'Biblical Theology' is still employed in a loose sense referring to studies of the Bible which take a generally History of Religions approach. It would be helpful if such inexact usage was avoided.

\section{iii. The rise and fall of Biblical Theology}

It is the case that Biblical Theology in the sense of the writing of works bearing that title virtually went out of existence for at least a century. Not everyone of course was swept along on the current of Religionsgeschichte. Moderate conservative scholars struggled to find a middle way between Rationalism and liberalism on the one hand and the older barren orthodoxy on the other. They also struggled to come to terms with the historical-critical approach to the Bible while still finding a way to regard Scripture as normative for Christian faith and life. A leading figure here is Adolf Schlatter (1852-1938) and it is significant that there has recently been a renewed interest in his work despite the fact that his views on specific issues require modification. ${ }^{19}$

${ }^{19}$ See R. Morgan, op. cit.; P. Stuhlmacher, 'Adolph Schlatter's Interpretation of Scripture', NTS 24 (1977-8) 433-46. 
The period following the First World War saw a major swing of the theological pendulum. The reaction within dogmatic theology led by Karl Barth had its counterpart in biblical studies in a renewed interest, particularly in Germany, in Old Testament Theology and to some extent also in New Testament Theology. W. Eichrodt is the best representative and the ablest exponent of this renewed emphasis on theology. He sought 'to understand the realm of Old Testament belief in its structural unity' as well as in 'its essential coherence with the New Testament' ${ }^{20}$ On the New Testament side the best known work is the brilliant if also controversial Theology of the New Testament by Rudolph Bultmann.

A succession of Old Testament and New Testament Theologies followed representing a variety of approaches. Can this be termed a renewal of Biblical Theology? Despite the reaffirmation of theology it is significant that the by now traditional division into Old Testament Theology and New Testament Theology was maintained. It is true that in the English-speaking world particularly we can discern a broad trend which some have labelled the biblical theology movement' and which climaxed in the 1950s. The so-called 'movement' drew heavy criticism from scholars such as James Barr, and its shortcomings have been documented in retrospect by B. Childs. ${ }^{21}$ While it brought forth much of value it failed to produce a single major work of Biblical Theology.22 The nearest it came to this was in the work of $O$. Cullmann, especially in his discussion of biblical thought in Christ and Time (1946, English translation 1950) and Salvation in History (1965, English translation 1967).

In face of internal weaknesses and external pressures the 'biblical theology movement' went into rapid decline and

\footnotetext{
${ }^{20}$ W. Eichrodt, Theologie des Alten Testaments, I, (Leipzig, J.C. Hinrichs 1933); ET, Theology of the Old Testament, Vol.1, (London, SCM 1961) 32.

${ }^{21}$ B.S. Childs, Biblical Theology in Crisis (Philadelphia, Westminste, 1970).

${ }^{22}$ A possible exception from this period might be M. Burrows, An Outline of Biblical Theology (Philadelphia, Westminster 1946), written from a liberal Protestant viewpoint, which is however more akin to a dictionary of biblical themes than a fully-fledged 'theology'. From the same period (but not the same 'movement') is the conservative Biblical Theology: Old and New Testaments (Grand Rapids, Eerdmans 1948) by G. Vos which unfortunately is incomplete.
} 
the 1960s and 1970s saw a strong counter-reaction with unprecedented emphasis on diversity and development within scripture. Not only was the possibility of a Biblical Theology denied ; even the writing of a true Old Testament Theology or a New Testament Theology was ruled out of court. At best Old Testament Theology dealt with the Deuteronomic theology, the theology of the Priestly source, the theology of II Isaiah and so on, while New Testament Theology gave way to the theology of Paul, of John, of 'early catholicism', and so on. Much academic study of the Bible seemed to consist largely of its dismemberment. ${ }^{23}$ Increasingly scholars seemed to share E. Käsemann's view that 'a biblical theology which is developed from one single root and maintained in unbroken continuity is an illusion and a phantom' ${ }^{24}$

\section{Recent Developments}

Recent years have seen a number of developments which suggest that plans for the funeral of Biblical Theology are perhaps premature. It is possible to offer here only the briefest sketch of some of these significant trends.

\section{i. Historical Criticism}

The role of historical criticism is being increasingly challenged not just by conservatives but within mainline biblical scholarship. It is not a case of "The End of the Historical Critical Method'.25 What is called in question is not the method itself but the use that has been made of it and especially the claims that have been made for it.

Scholars employing historical criticism have frequently regarded the biblical material as data from which to reconstruct the history and religion of Israel and the early Church. They have tended to look not so much at the biblical

${ }^{23}$ Cf. L. Houlden, 'Is The Bible Still There?', Theology 89 (1986) 87.

${ }^{24}$ E. Käsemann, 'Neutestamentliche Frage von heute', ZTK 54 (1957) 18. Cf. J. Barr, 'Trends and Prospects in Biblical Theology', JTS 25 (1974) 270, 'The tendency now is to say that there is no one theology, either of the Old Testament or of the New, and still less of the entire Bible'.

${ }^{25}$ The title of a book by G. Maier, The End of the Historical Critical Method (St. Louis, Concordia, 1977). For a critique see P. Stuhlmacher, Historical Criticism and Theological Interpretation of Scripture (Philadelphia, Fortress 1977) 66-71. 
text as through the text to the history which lies behind it, even though the results of such historical reconstruction are often far from assured. There has frequently been a tendency to assume that only the original form of a tradition is 'authentic'. Thus, for example, the 'Appendix of Hope' (Amos 9:8c-15) must be deleted in order to get back to the historical Amos; John's Gospel must be shorn of the (hypothetical) 'ecclesiastical redactor's' eschatology and sacramentalism in order to reveal the true Johannine theology.

One type of reaction to this has been J.A. Sanders' form of 'canonical criticism' which stresses that it is not just the original levels of tradition which are important but the whole process of transmitting, editing and shaping the material within the believing community up to and including the final canonical form. ${ }^{26}$

The claim that historical criticism can by-pass later Christian dogma and tradition and in an objective and impartial way rediscover 'the real Jesus' or 'the essence of Christianity' is widely challenged. It is in this sense that C. Davis has asserted that 'historical criticism of the Bible, while it may still have a glorious future as a branch of history, would seem to be near the end of its career in theology'. ${ }^{27}$

There has been increasing recognition of the fact that there can be no interpretation of texts without pre-suppositions. Modern hermeneutical theory especially as influenced by the work of H.-G. Gadamer ${ }^{28}$ recognizes that not only is the text historically conditioned but so also is the interpreter; we all bring to the text our own pre-judgment (Vorurteil). Gadamer sees interpretation as involving 'the fusion of horizons' (Horizontverschmelzung) - the horizon of the text and the

${ }^{26}$ J.A. Sanders, Torah and Canon (Philadelphia, Fortress, 1972); Canon and Community: A Guide to Canonical Criticism (Philadelphia, Fortress 1984).

${ }^{27}$ See his perceptive article, 'The Theological Career of Historical Criticism of the Bible', Cross Currents 32 (1982) 267-84, quotation from p. 267.

${ }^{28}$ H.-G. Gadamer, Truth and Method (New York, Seabury, 1975). See the detailed discussion in A.C. Thiselton, The Two Horizons: New Testament Hermeneutics and Philosophical Description with Special Reference to Heidegger, Bultmann, Gadamer and Wittgenstein (Grand Rapids, Eerdman, 1980). A helpful concise summary is found in R.L. Maddox, 'Contemporary Hermeneutic Philosophy and Theological Studies', Religious Studies 21 (1985) 517-29. 
horizon of the interpreter. This does not mean however that the interpreter's pre-judgments go unquestioned or that they determine the interpretation of the text. On the contrary, the interpreter must remain open to the text, to its 'quality of newness' and must be prepared to change his or her prejudgments. ${ }^{29}$ The underlying assumptions of many practitioners of historical criticism have frequently been rationalistic and positivistic. While claiming to be neutral and objective, many scholars have in fact ignored the most central assertions of the biblical texts themselves, those relating to the presence and activity of God within both nature and human history. It is in reaction to such false claims to objectivity that scholars such as $P$. Stuhlmacher have called for 'a Hermeneutics of consent to the biblical texts' which will be marked by 'a willingness to open ourselves anew to the claim of tradition, of the present, and of transcendence' ${ }^{30}$ G. F. Hasel has argued for an approach to Biblical Theology 'that seeks to do justice to all dimensions of reality to which the biblical texts testify'.$^{31}$ Linked with this there has been a growing awareness of the impossibility of making a rigid distinction between what a text 'meant' and what it 'means'. 32

\section{ii. The literary approach}

There has been considerable renewed interest in recent years in the appreciation of the Bible as literature. There is a wide diversity of 'literary approaches' but many of them agree at least in their focus on the final form of the text. Their approach tends to be synchronic rather than diachronic. They seek to look not through the text to the history which lies behind it but at the text as it stands. They also tend to underline how a literary work, once it has achieved its final written form, attains a life of its own, independent of the

\footnotetext{
${ }^{29}$ See A.C. Thiselton, op. cit, 304f.; Maddox, op. cit., 522. Cf. also H.H. Schmidt's discussion of the impossibility of separating objective description and hermeneutical reflection in Was heisst "Biblische Theologie"?', in H.F. Geisser and W. Mostert, Wirkungen hermeneutischer Theologie (Zürich, Theologischer Verlag 1983) 43.

${ }^{30} \mathrm{P}$. Stuhlmacher, op. cit, $83,85$.

${ }^{31}$ G.F. Hasel, 'Biblical Theology: Then, Now and Tomorrow', HBT 4:1 (1982) 66.

${ }^{32}$ See the discussion in G.F. Hasel, 'The Relationship Between Biblical Theology and Systematic Theology', 117-25.
} 
historical circumstances which gave it birth. Some exponents of the literary approach have focused on relatively small units of the biblical texts; structuralism, for example, has been applied to parables or to a passion narrative. A literary critic such as Northrup Frye, however, looks at the entire Bible as a literary whole. While well aware of the findings of historical criticism (e.g Pentateuchal source analysis), Frye regards these as irrelevant for his approach which deals with the Bible as it has come down within the Christian tradition and as it has exerted a tremendous influence on English literature. What impresses him is the continuity of biblical thought which he views as a sequence or dialectical progression consisting of seven main phases which run from creation to apocalypse. ${ }^{33}$

\section{iii. Tradition History}

There have also been recent signs that biblical scholarship cannot remain forever content with the rigid division between Old Testament and New Testament studies. This is seen particularly in the 'History of Traditions' approach associated with $\mathrm{H}$. Gese and P. Stuhlmacher, which is influenced by the work of Gerhard von Rad. Gese contends that in the time of Jesus there was not yet a closed canon of the Old Testament, and what Biblical Theology deals with is 'a unified process of tradition of the Old and New Testaments viewed as a whole' ${ }^{\prime 34}$ Divine revelation is not to be located only in the earliest forms of the tradition but in the entire process, which was long and complex as traditions were continually selected, edited and re-interpreted. Gese has, for example, traced the concept of Wisdom in the Old Testament, through the intertestamental period and on into the New Testament, where it makes a major contribution to Christology. ${ }^{35}$ Similarly Stuhlmacher has studied 'The Law as a Topic of Biblical Theology', tracing differing and developing concepts of law through both Testaments. ${ }^{36}$

\footnotetext{
${ }^{33}$ N. Frye, The Great Code: The Bible and Literature (Toronto, Academic Press 1981).

${ }^{34} \mathrm{H}$. Gese, Essays on Biblical Theology (Minneapolis, Augsburg 1981) 15.

${ }^{35} \mathrm{H}$. Gese, ' Wisdom, Son of Man and the Origins of Christology: The Consistent Development of Biblical Theology', HBT 3 (1981) 23-57. See also Vom Sinai zum Zion: altestamentliche Beiträge zum biblischen Theologie (Munich, Kaiser 1977).

${ }^{36}$ In Reconciliation, Law and Righteousness (Philadelphia, Fortress 1986) 110-
} 
This approach has been hailed as a new form of Biblical Theology, but it has also been the subject of much criticism. ${ }^{37}$ The process of tradition is a matter of historical reconstruction and involves assumptions frequently challenged by other critical scholars. The tracing of a continuous development of tradition also involves the use of non-canonical inter-testamental material. In these respects the approach is more historical than canonical. Further, when revelation is located in the entire process of tradition history it is not always clear where Christian faith is to find its norm. Despite these criticisms there is much of value in this approach which bridges the gap between Old Testament and New Testament scholarship.

Significant also in this regard was the growing interest in the 1980s in tracing individual biblical themes through both Old and New Testaments as in the Fortress Press series Overtures to Biblical Theology, and Abingdon's Biblical Encounters series. While not ignoring diversity these tend to bring out continuity in biblical themes and also to present the material in a way which will speak to the concerns of the contemporary believer. ${ }^{38}$ "The yearning and expectation of believers', say the editors of the Overtures series, 'will not let biblical theology rest with the descriptive task alone. The growing strength of Evangelical Protestantism and the expanding phenomenon of charismatic Catholicism are but vocal reminders that people seek in the Bible a source of alternative value systems. By its own character and by the place it occupies in our culture the Bible will not rest easy as merely an historical artifact'. ${ }^{39}$

iv. The interpretive community

33.

${ }^{37}$ See H.G. Reventlow, Problems of Biblical Theology in the Twentieth Century, 149-54; H. Hübner, 'Biblische Theologie und Theologie des Neuen Testaments: Eine programmatische Skizze', KD 27 (1981) 3-5. G.F. Hasel has asked whether this is actually Biblical Theology or a theology of traditionbuilding': see 'Biblical Theology: Then, Now and Tomorrow', 66.

${ }^{38}$ See e.g. W. Brueggemann, The Land, Overtures to Biblical Theology 1 (Philadelphia, Fortress, 1977); E.S. Gerstenberger and W. Schrage, Suffering, Biblical Encounters Series (Nashville, Abingdon 1980).

${ }^{39} \mathrm{~W}$. Brueggemann, op. cit., $x$. 
The latter point is linked with another significant trend in recent years. There have always been scholars who have sought to bridge the gap between academic study of the Bible and its practical application in the life of the Church though their voices have often been muted in a world of increasing academic specialization. There appears now to be a belated recognition on the part of an increasing number of biblical scholars of their responsibility to the community of faith. One of the strongest criticisms being voiced of the historical-critical approach concerns the way in which it has tended to separate the Bible from the life and work of the Church, the community to which the Bible belongs. Various types of 'reader-response criticism' have stressed the role of the reader in the interpretation of a text. In the thought of Stanley E. Fish, texts have meaning only in the context of 'interpretive communities'..$^{40}$ Now it is clear that the appropriate 'interpretive community' for the Bible is the Church, the community which accepts the Bible as its canonical scriptures. The Bible is most truly interpreted in relation to its canonical intention not when it is dissected by historical critics, but when it is read as the Word of God by the People of God. It is the Church which constitutes the true readership of scripture, ${ }^{41}$ though of course the Church must constantly scrutinize its faith and life in the light of the Word of God conveyed by scripture.42

The Church has never stopped using the Bible in the on-going task of dogmatic theology, in wrestling with contemporary ethical questions, in its worship (cf. the growing use of a lectionary with Old Testament, Epistle and Gospel readings), in countless weekly sermons, in Bible study groups, and so on. All these must work with some kind of 'Biblical Theology',

\footnotetext{
${ }^{40}$ S.E. Fish, Is There a Text in This Class? The Authority of Interpretive Communities (Cambridge, Harvard University Press 1980) 171, 172.

${ }^{41}$ P.D. Hanson, 'The Responsibility of Biblical Theology to the Community of Faith', TT 37 (1980) 39-50 stresses that the biblical text and the contemporary life of the community of faith form the two poles of the interpretive process. Cf. S. Schneider, 'Church and Biblical Scholarship in Dialogue', TT 42 (1985) 353-8.

${ }^{42} \mathrm{Cf}$. G. Siegwalt, 'La théologie Biblique: Concept et réalisation', ETR 54 (1979) 400: 'Biblical theology cannot be other than an ecclesial science. It is in service to the edification of the Church, and it has a critical function vis-a-vis the Church'.
} 
some at least provisional view of the understanding of God in his relation to the world and mankind contained in the scriptures of both Old and New Testaments. It is somewhat ludicrous that while millions of Christian believers struggle to attain a more satisfactory form of Biblical Theology there are still many biblical scholars who maintain that there is no such thing! ${ }^{43}$

It is in this context that W. Wink makes his perhaps overly dramatic assertion that 'Historical biblical criticism is bankrupt'. By this he does not mean that the historical approach is valueless. 'Biblical criticism is not bankrupt because it has run out of things to say or new ground to explore. It is bankrupt solely because it is incapable of achieving what most of its practitioners considered its purpose to be: so to interpret the Scriptures that the past becomes alive and illumines our present with new possibilities for personal and social transformation'. ${ }^{44}$

\section{v. The canonical approach}

Most significant of all for the future of Biblical Theology is the development of the 'canonical approach' to Scripture, associated primarily with the name of Brevard Childs who has argued that it is the Scriptures of the Old and New Testaments in their final canonical form which provide the true context of Biblical Theology. 'The significance of the final form of the biblical text', says Childs, 'is that it alone bears witness to the full history of revelation'.45 First enunciated in his Biblical Theology in Crisis, then worked out in a commentary on Exodus,

\footnotetext{
${ }^{43}$ See S. Wagner, 'Zur Frage nach der Möglichkeit einer biblischen Theologie', TL 113 (1988) 163, 'Preachers involved in parish work are compelled as it is, because of pastoral needs, to practise a "biblical theology", regardless of whether it has been thought through or not. This must often enough be attained and maintained without any effective help on the part of scholarly theology'. Cf. also B.S. Childs, 'Some Reflections on the Search for a Biblical Theology', HBT 4:1 (1982), especially 8.

${ }^{44} \mathrm{~W}$. Wink, The Bible in Human Transformation: Toward a New Paradigm for Biblical Study (Philadelphia, Fortress 1973) 1, 2.

${ }^{45}$ B.S. Childs, Introduction to the Old Testament as Scripture (Philadelphia, Fortress 1979) 40. See the discussion by S. Fowl, The Canonical Approach of Brevard Childs', ET 96 (1985) 173-6, who compares Childs with Gadamer in their common insistence on the necessity of interpreting a text from within a tradition.
} 
in introductions to both Old and New Testaments, and especially most recently in a volume on Old Testament Theology, ${ }^{46}$ Childs' proposals open up the possibility of a new direction for Biblical Theology. Some critics have been alarmed at what they see as a denigration of the historical critical approach, ${ }^{47}$ and the relation between the historical and canonical approaches perhaps still needs further clarification. Up to the present Childs' work has remained within the customary Old Testament/New Testament compartments and has not advanced to a truly 'biblical' theology though it has the potential for so doing.8

\section{A New Approach to Biblical Theology}

Each of these recent trends must be carefully examined and critically assessed. Nevertheless it may be suggested that there is a certain convergence of tendencies which provides a climate in which a new approach to Biblical Theology may be possible.

\section{i. An intermediate Biblical Theology}

Since the rise of modern historical consciousness there can be no going back to a precritical integrated Biblical Theology. On the other hand, the pursuit of a totally independent Biblical Theology (as distinct from a history of Israelite or early Christian religion) has proved to be self-defeating. What does hold promise is an approach which sees Biblical Theology as a bridge discipline ${ }^{49}$ situated between the historical (and literary) study of scripture on the one hand and its use by the

\footnotetext{
${ }^{46}$ B.S. Childs, Old Testament Theology in a Canonical Context, (London, SCM 1985).

${ }^{47}$ See for example the critiques by Birch, Knight, Mays, Polk and Sanders, and the reply by B.S. Childs in HBT 2 (1980) 113-211. Also S. Wagner, 'Zur Frage nach der Möglichkeit einer biblischen Theologie', 65.

${ }^{48}$ Old Testament Theology in a Canonical Context, despite some tentative attempts to link Old Testament themes with the New Testament, is still primarily Old Testament Theology in the context of the Old Testament canon, rather than Old Testament Theology in the context of the biblical canon.

${ }^{49}$ For the 'bridge' metaphor cf. G. Goldsworthy, Gospel and Kingdom: $A$ Christian Interpretation of the Old Testament, (Exeter, Paternoster 1981) 43. To vary the metaphor, what R.P. Knierim says of Old Testament Theology applies equally to Biblical Theology: 'It is the indispensable and distinct relay-station between exegesis and systematic theology or hermeneutics' HBT 6:1 (1984) ('The Task of Old Testament Theology', 47).
} 
Church in dogmatic theology and related areas on the other. This may thus be termed an intermediate Biblical Theology.

There can be no question of dispensing with the historical critical approach (though the question of presuppositions has to be addressed). Historical criticism can be of great value in illuminating 'the horizon of the text'. Questions of authorship, date and so on have to be based on critical examination of all the evidence. There is no short-cut to the work of exegesis of the biblical texts. The study of the Bible book by book and author by author is a legitimate and necessary undertaking. An intermediate Biblical Theology will assume and accept all this. But when all the work of analysis has been done there remains the possibility and indeed the necessity of attempting some kind of synthesis of the biblical material. It is this aspect which is stressed by E.A. Martens when he defines Biblical Theology as 'that approach to Scripture which attempts to see Biblical material holistically and to describe this wholeness or synthesis in Biblical categories. Biblical theology attempts to embrace the message of the Bible and to arrive at an intelligible coherence of the whole despite the great diversity of the parts. Or, put another way: Biblical theology investigates the themes presented in Scripture and defines their inter-relationships. Biblical theology is an attempt to get to the theological heart of the Bible'.50

In one sense Biblical Theology is still concerned to illuminate 'the horizon of the text', in all its fullness and complexity, though in the context of the total biblical canon. But it is naive to think that this can be done in any neutral or objective fashion. Biblical Theology is inevitably part of the hermeneutical process and is already involved in the movement towards 'the fusion of horizons'. It does not claim to be purely descriptive or objective. Its presuppositions, based on a Christian faith commitment, include belief that the Bible conveys a divine revelation, that the Word of God in Scripture constitutes the norm of Christian faith and life, and that all the varied material in both Old and New Testaments can in some way be related to the plan and purpose of the one God of the whole Bible. Such a Biblical Theology stands somewhere between

${ }^{50}$ E.A. Martens, Tackling Old Testament Theology', JETS 20 (1977) 123 -32. 
what the Bible 'meant' and what it 'means'. It seeks to mediate the results of specialized biblical studies to those whose primary concern is the appropriation and application of God's word, conveyed through Scripture, to the faith and life of the Church today. ${ }^{51}$

It is interesting to note that what J.P. Gabler actually proposed in his 1787 address included what could be termed a form of 'intermediate Biblical Theology'. ${ }^{52}$ (Of course, there is no law which says that Biblical Theology has to mean what J.P. Gabler held it to mean!). Gabler identified himself as among those 'devoted to the sacred faith of Christianity', who 'profess with one united voice that the sacred books, especially of the New Testament, are the one clear source from which all true knowledge of the Christian religion is drawn'..$^{53}$ In the Christian use of 'the sacred books' Gabler distinguished not two but three stages. The first two he subsumed under the heading 'biblical theology', though he later distinguished these as 'true (wahre) biblical theology' and 'pure (reine) biblical theology'.54 Stage one is the historical study of the Old and New Testaments and of the individual authors and periods. But this was to be followed by a second stage consisting of 'a careful and sober comparison of the various parts attributed to each testament' (190) with the purpose of distinguishing those opinions 'which have to do with the unchanging testament of Christian doctrine, and therefore pertain to us directly' from those which 'are said only to men of some particular era or testament' (191). In other words this part of Biblical Theology was not merely descriptive but very definitely also interpretative; it selected

\footnotetext{
${ }^{51}$ Cf. E. Jacob's call for a dialogue between Biblical Theology and Dogmatics: 'Possibilités et limites d'une théologie biblique', RHPR 46 (1966) 117; also P. Pokorny, 'Probleme biblischer Theologie', TL 106 (1981) 1. H. Seebass, while defining Biblical Theology as the theology contained in the Bible, emphasizes that it can only be undertaken in relation to the challenges facing the Christian Church today: see Der Gott der Ganzen Bibel (Freiburg, Herder 1982) 7-27.

${ }^{52}$ Cf. A.W. Walker-Jones, "The Role of Theological Imagination in Biblical Theology', HBT 11:1 (1989) 75-8, who points out that Gabler's main interest was not in the history of religion but in theology and the Church.

${ }_{53} \mathrm{~J}$. Sandys-Wunsch and L. Eldredge, op. cit., 179, 180.

${ }^{54} \mathrm{~J}$. Sandys-Wunsch and L. Eldredge, op. cit., 157, n. 1 . In this paragraph the page numbers in brackets refer to the Sandys-Wunsch/Eldredge translation of Gabler's address. Cf. the discussion in J.H. Hayes and F.C. Prussner, op. cit., 625.
} 
from the Bible universal and unchanging truths. These were to be 'carefully collected', 'suitably digested' and 'cautiously compared among themselves' (191). This collection of material would then show 'with unambiguous words the form of faith that is truly divine' (192), and the result will be 'biblical theology in the stricter sense of the word' (192). It is this 'pure biblical theology' which is then to be used by the dogmatic theologian and related to the thought of his own day.

This 'pure Biblical Theology' is thus an intermediate discipline lying between the exclusively historical and descriptive form of Biblical Theology and the exclusively normative dogmatic theology. Gabler's proposals were so closely tied to his Rationalist presuppositions that stage two was in effect ignored and Gabler came to be quoted over and over again as advocating a complete separation of historical and dogmatic, of descriptive and normative theology. Gabler's Rationalist approach is completely unacceptable: it reduces the biblical word to universal and timeless truths, failing to grasp the nature of revelation in history; it in fact eliminates a considerable amount of the biblical material as inapplicable to modern believers; and it severely limits the extent to which God may be thought of as active in both nature and history. What is suggested here, however, is that one aspect of Gabler's proposal, namely an intermediate position for Biblical Theology between historical study and dogmatics, can be salvaged and reinstated in a new way and with a new methodology.

\section{ii. A canonical Biblical Theology}

What has broken the log-jam in contemporary biblical studies is the recognition of the central importance of the biblical canon to Biblical Theology. Biblical theology is canonical theology. Literary studies, as we have noted, have made their contribution through focusing on the canonical text. But it is the proposals of B. Childs which have had the most significant effect. Biblical Theology is canonical theology, it is here proposed, in three main senses.

a) Biblical Theology is canonical theology in that it is concerned with both Old and New Testaments together. Recent German discussion has focused on the question of 'eine gesamtbiblische Theologie', ('an all-biblical theology'), a phrase 
used to indicate that what is in view is not Old Testament Theology plus New Testament Theology, but a theology which encompasses both Testaments. ${ }^{55}$

There are two aspects of this which must somehow be held together. On the one hand a canonical Biblical Theology must seek to do full justice to the Old Testament. All too often the separation of Biblical Theology into Old Testament and New Testament Theology has meant the ignoring or downplaying of the Old Testament. A renewed Biblical Theology can play a major role in overcoming this tendency. S. Terrien has gone so far as to declare that the Old Testament is beginning to receive for the first time in the history of the church its rightful place and modern forms of Marcionism are at last being rejected as theological anti-Semitism' ${ }^{56}$ Terrien himself has led the way with his work The Elusive Presence which represents the first major scholarly attempt to write a truly Biblical Theology encompassing both Old and New Testaments in over a century. ${ }^{57}$ It has been followed by a work similar in scope by a German Old Testament scholar Horst Seebass, Der Gott der Ganzen Bibel ('The God of the Whole Bible'). ${ }^{58}$ Both these works are characterized by their sympathetic presentation of the Old Testament.

On the other hand, however, in a canonical Biblical Theology the Old Testament cannot be viewed on its own but only from the perspective of the Christian canon as a whole. It follows that 'Old Testament Theology' as part of Biblical Theology must be a Christian discipline. Of course, what Christians call the 'Old Testament' also constitutes the scripture of Judaism. It has often been noted that Jews have shown little or no interest in Biblical Theology. While this may be

\footnotetext{
${ }^{55}$ On the phrase see $P$. Höffken, op. cit., 13; also $H$. Hübner, 'Biblische Theologie und Theologie des neuen Testaments', 2. Hübner himself however believes 'that for the present time at least there is no question of producing an overall design in which the Old Testament and the New Testament in their differing central affirmations would be presented in a convincing way as a theological whole' (8).

${ }^{56} \mathrm{~S}$. Terrien, "The Play of Wisdom; Turning Point in Biblical Theology', HBT 3 (1981) 125.

${ }^{57}$ S. Terrien, The Elusive Presence: The Heart of Biblical Theology (San Francisco, Harper and Row 1978).

${ }^{58} \mathrm{H}$. Seebass, op. cit.
} 
due in part to historical accident, ${ }^{59}$ it is also due to the nature of Judaism which has been more interested in orthopraxis than orthodoxy, which has not been concerned with the systematization of belief, and in which the relation of Tanakh to Talmud and Midrash has been quite different from that of the Old Testament to the New Testament. ${ }^{60}$ In principle, however, there could be a Jewish theology of the Hebrew scriptures, but by definition it could not be 'Old Testament' or 'Biblical' Theology. It would more properly be designated perhaps as "Tanakh Theology" 61 and its presuppositions would of course be different from those of Old Testament Theology. ${ }^{62}$ The two disciplines of Tanakh Theology and Old Testament/Biblical Theology could exist alongside one another, could engage in dialogue and learn from each other, but they could never coalesce. ${ }^{63}$

Recently several scholars have challenged the view that Old Testament Theology must be a Christian discipline. J.L. McKenzie claims to have written his $A$ Theology of the Old Testament 'as if the New Testament did not exist';64 R.P. Knierim has called for a 'focus on the Old Testament in its own right';65 and R. Rendtorff has contended that 'we should examine the theology of the Hebrew Bible independently of any later religious developments, whether Christian or Jewish' ${ }^{66}$

\footnotetext{
${ }^{59}$ See W.E. Lemke, 'Is Old Testament Theology An Essentially Christian Theological Discipline?', HBT 11:1 (1989) 60.

${ }^{60} \mathrm{Cf}$. M. Tsevat, 'Theology of the Old Testament - A Jewish View', HBT 8:2 (1986) 36, 37; J.D. Levenson, 'Why The Jews Are Not Interested In Biblical Theology', in J. Neusner et al., edd., Judaic Perspectives on Ancient Israel (Philadelphia, Fortress 1987); W.E. Lemke, op. cit.

${ }^{61}$ Cf. M. Goshen-Gottstein, 'Tanakh Theology: The Religion of the Old Testament and the Place of Jewish Biblical Theology', in P.D. Miller et al., edd., Ancient Israelite Religion (Philadelphia, Fortress, 1987) 617-44.

${ }^{62} \mathrm{Cf}$. P. Pokorny, 'Probleme biblischer Theologie', 4, 5; P. Höffken, op. cit., 17.

${ }^{63}$ Despite the article cited above, J.D. Levenson in Sinai and Zion (Minneapolis, Winston, 1985) has written an important study of two major themes of the Hebrew Scriptures which is in fact a form of Tanakh Theology! Just as he has drawn on the work of Christian as well as Jewish scholars, so also he expresses the hope that his study may help the Christian to hear 'tones that his own tradition has muted or hushed' (p.12).

${ }^{64} \mathrm{Op}$. cit., 319.

65.P.P. Knierim, op. tic., 52.

${ }^{66} \mathrm{R}$. Rendtorff, 'Must "Biblical Theology" Be Christian Theology?' Bible Review 4 (1988) 42.
} 
These scholars are reacting against a false 'Christianizing' of the Old Testament and demonstrating a commendable desire to allow the authentic voice of the Old Testament to be heard. This may be appropriate at the level of historical study of the Old Testament, but a canonical Biblical Theology as defined here is concerned with the Old Testament along with the New Testament as the two parts of canonical scripture and hence inevitably involves Christian presuppositions. What is maintained here is that Biblical Theology can both do justice to a historical study of the Old Testament and hold that in the context of the canon the New Testament is its continuation and fulfilment.

'Biblical Theology', G.F. Hasel contends, 'must integrate Old and New Testament theology in a dynamic way that overcomes the present juxtaposition. ${ }^{67}$ This means that a major concern of Biblical Theology is the understanding of the theological relationship between Old Testament and New Testament, a question with which the Church has had to wrestle, not just in the historical-critical period, but throughout the era of 'integrated Biblical Theology'.68

(b) Biblical Theology is canonical theology in that it is based primarily on the final canonical form of Scripture. The word 'primarily' is important. As a bridge discipline, an intermediate Biblical theology presupposes and builds on historical (and literary) study of individual books and authors. But it goes on from there to recognize that what the Church has always accepted as canonical is the final form of the text. The Church did not canonize J, E, D or P, nor did it canonize $Q$ or Proto-Luke. What is significant about the Book of Amos is that it was not

${ }^{67}$ G.F. Hasel, 'Biblical Theology: Then, Now and Tomorrow', 74. Cf. G. Siegwalt, 'La théologie Biblique; Concept et réalisation', 409: 'Biblical theology properly understood does not limit itself to the Old or the New Testament, but views them together'; R. de Vaux, 'A propos de la Théologie Biblique', ZAW 68 (1956) 226: 'For the Christian scholar who works in the light of his faith, there is no theology of the Old Testament separated from a theology of the New Testament, there is only a biblical theology founded on the two testaments which both contain the Word of God'.

${ }^{68}$ Cf. G. Ebeling, 'The Meaning of "Biblical Theology"', 96: 'In "Biblical Theology" the theologian who devotes himself specially to studying the connexion between the Old and New Testaments has to give an account of his understanding of the Bible as a whole'. 
accepted into the canon without the 'Appendix of Hope', just as John was only accepted in the 'ecclesiastically redacted' form (if that is what it is). A book may mean one thing on its own, and in its original historical setting. By being placed within the canon it acquires new shades of meaning and it is with this larger canonical meaning that Biblical Theology must primarily deal.

(c) Biblical Theology is canonical theology in that it seeks to deal with the full range of canonical materials. This means that it will be resolutely opposed to any form of a 'canon within the canon'. From an early period there have been those who have sought to interpret Scripture selectively, highlighting those parts found most congenial while relegating to an inferior position those portions which do not accord with their chosen theological perspective. The attraction of such an approach is that it provides a way of dealing with the diversity of Scripture and of producing a more unified interpretation.

Thus already in the 2 nd century Marcion not only rejected the Old Testament but accepted only Luke's Gospel and ten letters of Paul (though even these only in an edited and expurgated version). Marcion's canon was certainly more compact and more consistent than that eventually recognized by the Church, but it is highly significant that the Church decisively rejected such a drastic 'canon within the canon' and opted for a much more broadly based selection incorporating a considerably greater variety than Marcion was prepared to allow.

Luther may be said to have produced his own 'canon within the canon' through his identification of those New Testament books which 'show Christ', i.e. those which are consistent with his hermeneutical principle of 'justification by faith'. Here again unity is purchased at a price - the devaluing of the canonical status of books such as Hebrews, James, Jude and Revelation. It is not difficult to catch echoes of this in Bultmann's emphasis in his Theology of the New Testament on Paul and John to the virtual exclusion of other books and authors. ${ }^{69}$

${ }^{69}$ It is noteworthy that Bultmann uses the term 'theology' only in the sections dealing with Paul and John; 'The Message of Jesus', 'The Kerygma of the Earliest Church' and 'The Kerygma of the Hellenistic Church Aside from Paul' 
Liberal theologians produced a quite different 'canon within the canon' by taking the teaching of the (rediscovered and reconstructed) historical Jesus as their hermeneutical key, and correspondingly devaluing Paul and the later books of the New Testament which were seen as representing a progressive 'theologizing' and 'Hellenizing' of the simple message of Jesus. Against all such tendencies those engaged in canonical Biblical Theology must make every effort to do justice to the biblical material in its totality. There will naturally be a concern to find some principle (or principles) which will bring coherence to the great mass of biblical material. But the temptation to find a short-cut through the selection of a 'canon within the canon' must be resisted. As P.D. Hanson puts it, 'we are pleading for an openness to the total address of Scripture, lest we select only what reinforces our present views and exclude the possibility of growth' ${ }^{70}$

A further implication is the strong desirability of including within the scope of a canonical Biblical Theology discussion of the biblical-theological basis of ethics. The biblical material itself sees the strongest possible connection between faith and life; biblical ethics are theological ethics. Until recently with a few exceptions Biblical Ethics was a field sadly neglected by biblical scholars. Significantly, one of the reasons cited for the collapse of the so-called 'Biblical Theology Movement' is the perception that it was irrelevant to the crises of the 1960s. ${ }^{71}$ B.S. Childs has contended that biblical theologians should be working on the burning issues of the day such as male/female relations, liberation theology, creation and ecology, marriage and the family. ${ }^{72}$ The actual discussion of

are all subsumed under the heading 'Presuppositions and Motifs of New Testament Theology', while all the remaining books are dealt with under the rubric of 'The Development toward the Ancient Church' which includes a subsection on 'The Development of Doctrine' (Die Entwicklung der Lehre). L. Morris in his New Testament Theology (Grand Rapids, Zondervan 1986) 9, comments that it appears that for Bultmann much of the New Testament is not theology, whereas in Paul and John we have two theologies.

${ }^{70}$ P.D. Hanson, The Diversity of Scripture: Trajectories in the Confessional Heritage (Philadephia, Fortress 1982) 4.

${ }^{71}$ See J.D. Smart, The Past, Present and Future of Biblical Theology, 131, 132. Cf. also B.S. Childs, Biblical Theology in Crisis, Chapter 7.

72B.S. Childs, 'Some Reflections on the Search for a Biblical Theology', 9. 
contemporary ethical problems belongs to the sphere of Christian Ethics which will take into account not only the biblical evidence but also all relevant factors in the contemporary situation. But from its intermediate position between the historical study of Scripture and modern theological reflection a canonical Biblical Theology should deal with the biblical basis for making ethical decisions.

\section{iii. A co-operative Biblical Theology}

Clearly there are many involved in the academic study of the Bible today who regard the kind of Biblical Theology being sketched out here as an entirely wrong-headed undertaking and indeed totally impossible of realisation. Others oppose it not so much on principle but rather on the more practical basis that such an enterprise is quite beyond the competence of any one individual in this day of ever-increasing academic specialization. ${ }^{73}$ It may indeed be that Biblical Theology must increasingly become a co-operative venture rather than the work of individuals. ${ }^{74}$

A truly Biblical Theology would undoubtedly benefit from the co-operation of Old and New Testament scholars. ${ }^{75}$ Certainly ways must be found to surmount the unhealthy overspecialization which sees New Testament and Old Testament studies as entirely separate disciplines each going their own way. The co-operation between H. Gese and P. Stuhlmacher

\footnotetext{
${ }^{73} \mathrm{Cf}$. H. Hübner, 'Biblische Theologie und Theologie des Neuen Testaments', 6:' In view of the present ramifications and complexities both in the area of Old Testament and New Testament disciplines, it exceeds the competence of any one particular exegete to have a command of the extent of both disciplines so that he might dare to write a theology embracing both Testaments'.

${ }^{74}$ Cf. B.A. Meyer, 'Critical Realism and Biblical Theology', in Critical Realism in the New Testament (Allison Park, Pickwick 1989) 208, who affirms that Biblical Theology 'supposes a powerful collaborative effort of scholarship'.

${ }^{75} \mathrm{Cf}$. G. Ebeling, "The Meaning of "Biblical Theology", 96. In practice studies in biblical theology (i.e. covering both Testaments) have more often been attempted by Old Testament than by New Testament scholars.
} 
provides a good example of how an Old Testament and a New Testament scholar can stimulate and inform one another's work.

Another form of co-operation might be between biblical and dogmatic theologians. ${ }^{76}$ If Biblical Theology is a bridge discipline linking historically-oriented biblical studies on the one hand and dogmatic theology and related fields on the other then the bridge may well be one which carries heavy traffic, and traffic in both directions. It is noteworthy that S.P.C.K. have recently launched a new series, Biblical Foundations in Theology, consisting of volumes co-authored by scholars in the fields of Biblical Studies and Systematic Theology. ${ }^{77}$

Of significance also is the growing co-operation between biblical scholars of different denominational and confessional backgrounds. ${ }^{78}$ Biblical Theology presents a continuing challenge to scholars to encompass the full range of biblical truth unencumbered by the blinkers of their own particular tradition. One recalls the saying that Protestantism is the religion of Paul, Roman Catholicism of Peter and Orthodoxy of John. This aphorism makes a valid point; the study of biblical theology is so easily limited by the partial perspectives which scholars of differing Christian traditions bring to their tasks.

One of the most significant developments of the 20th century has been the changed attitude of the Roman Catholic Church towards the study of Scripture which has permitted Roman Catholics to enter the main stream of biblical scholarship. Equally important have been changing attitudes on the part of conservative-evangelicals which have resulted in a rising standard of scholarly competence and a willingness to enter into dialogue with the world of biblical scholarship. Less numerous but nonetheless welcome are contributions from the Eastern Orthodox tradition. ${ }^{79}$

${ }^{76} \mathrm{Cf}$. S. Wagner, ' Zur Frage nach der Möglichkeit einer biblischen Theologie', 163; D. Jodock, 'The Reciprocity Between Scripture and Theology; The Role of Scripture in Contemporary Theological Reflection', Int 44 (1990) 369-82.

${ }^{77}$ See the first volume by J.G.D. Dunn and J.P. Mackay, New Testament Theology in Dialogue (London, SPCK 1987).

${ }^{78} \mathrm{Cf}$. E. Jacob, 'Possibilités et limites d'une théologie biblique', 129, 130; P.S. Watson, 'The Nature and Function of Biblical Theology', ET 73 (1961-2) 200.

${ }^{79}$ For Orthodox biblical scholarship see the publications of St. Vladimir's Seminary Press especially G. Cronk, The Message of the Bible: An Orthodox Christian Perspective (Crestwood, N.Y., St.Vladimir's Seminary Press 1982). 


\section{iv. A structured Biblical Theology}

Is Biblical Theology an activity or a literary genre? Is it a dimension of exegesis or of the study of individual books or themes, or must it be embodied in volumes which bear the title 'Biblical Theology'? The first of these alternatives does not lack proponents. H.H. Schmidt, for example, regards Biblical Theology not as a separate subject at all but rather as 'a task which is entrusted to all theological disciplines' ${ }^{80}$ B.C. Ollenberger sees Biblical Theology 'more as an activity (helping the church to engage in critical reflection on its praxis through a self-critical reading of its canonical text) rather than as a genre of literature' ${ }^{81}$

Certainly the exegesis of a text can be part of Biblical Theology provided that the text in question is looked at not just in the context of the book in which it appears but also in a total biblical context. Studies of individual books are not of themselves necessarily part of Biblical Theology unless they too are discussed not in isolation but in the total canonical context. Studies of particular themes or topics which are traced through both Old and New Testaments are clearly a form of Biblical Theology.

The question has to be raised, however, as to whether Biblical Theology can remain content with such a fragmented approach, or whether all such studies of individual texts, books or themes do not imply, implicitly if not explicitly, a broader framework or structure of some kind for understanding the canonical material as a whole. Can any passage or theme from the Old Testament be studied in the context of Christian belief without enquiring regarding its relation to corresponding passages and themes in the New Testament, and thereby inevitably implying a larger framework for understanding the relationship between the Testaments? Can a biblical passage on a particular ethical question be studied without relating it to the other main biblical passages on the same theme, thereby inevitably raising the question of a broader framework for

${ }^{80}$ H.H. Schmidt, Was heisst "Biblische Theologie"?' 49.

${ }^{81}$ B.C. Ollenberger, 'Biblical Theology: Situating the Discipline', in J.T. Butler et al., edd., Understanding the Word: Essays in Honor of Bernhard W. Anderson (Sheffield, JSOT Press 1985) 51. 
dealing with questions of unity and diversity within Scripture?

In the period of 'integrated Biblical Theology' these were matters of central concern to the Church (even though we may not be able today to subscribe to all the methods proposed for the solution of such problems). The period of 'independent Biblical Theology' began with the writing of 'Biblical Theologies' but as a genre these died out as the canonical context became lost and Biblical Theology was interpreted as a purely historical and descriptive discipline. The question which arises in the new situation at the present time is whether the 'broader framework' or structure essential for understanding individual passages, books and themes could be provided by the writing of a new kind of 'Biblical Theology'. The questions of methodology and structure involved in such a proposal are complex and discussion of these is reserved for a subsequent article.

The production of such a Biblical Theology would indeed be a daunting task; yet it could be argued that it is the greatest single challenge facing biblical scholarship at the present time. Today, as for the last 150 years, the very possibility of a Biblical Theology continues to be called in question by large numbers of academic biblical scholars. For many the whole concept of Biblical Theology is dead; but it is just possible that in true biblical fashion it will rise again.

Part II of this discussion, 'The Structure of Biblical Theology' will appear in Volume 42.2 (November 1991). 